\title{
Sex differences in the $\alpha$-tocopherol requirement of rats as shown by the haemolysis test
}

\author{
BY R. J. WARD* \\ Dunn Nutritional Laboratory, University of Cambridge and Medical Research Council
}

(Received I8 Fuly 1962-Revised I7 September 1962)

In experiments carried out to determine the biological activity of the various tocopherol homologues (Ward, 1958a), it was observed that female rats appeared to require less tocopherol than the males to prevent haemolysis of the erythrocytes (György \& Rose, I949). Rose \& György (1950) reported that a daily intake of $3 \mathrm{mg}$ DL- $\alpha$-tocopherol $/ \mathrm{kg}$ body-weight was sufficient to prevent the erythrocytes of female rats from becoming sensitive to dialuric acid, but they apparently did not study the requirement of the male. Observations made by Taylor (1958) on the exposure of rats deficient in vitamin $\mathrm{E}$ to high oxygen pressure indicated that the erythrocytes of males were more liable to haemolysis than those of females. Sharman \& Richards obtained another indication of sex difference, but did not report it when they described cognate experiments in which they showed that Hovis bread, rich in wheat germ, was able to protect the erythrocytes of rats from haemolysis by dialuric acid (Sharman $\&$ Richards, 1960). When rats that had been fed for some time on Hovis bread received a diet of commercial white bread made from flour in which the tocopherol had been destroyed by treatment with chlorine dioxide, the erythrocytes of the females were still protected after $2 \mathrm{I}$ days, whereas extensive haemolysis was observed in those of the males.

It seemed important to ascertain whether the apparently larger requirement of the male for $\alpha$-tocopherol was due only to its larger size or whether the sex difference would persist even if dosage were strictly related to body-weight.

This paper describes in greater detail, and includes further experimental evidence for, results already given in a preliminary communication (Ward, 1958b).

\section{EX P ER I M EN T A L}

Expt I. From weaning, three groups, each consisting of two male and two female piebald rats, were given a diet deficient in vitamin E (Table 1 ), together with weekly supplements of rooo i.u. vitamin $A$ as the acetate, $60 \mathrm{i} . u$. vitamin $\mathrm{D}_{3}$ and $50 \mu \mathrm{g}$ vitamin $\mathrm{K}$ as 2 methyl-I,4-naphthoquinone. Water was provided ad lib. The animals were weighed weekly; in the first experiment they were given weekly $2 \cdot 0,2.5$ or $3.0 \mathrm{mg} \mathrm{DL}-\alpha$-tocopherol $/ \mathrm{kg}$ body-weight in two equal oral doses from the $42 \mathrm{nd}$ day of the experiment. The haemolysis test of György \& Rose (1949) as modified by Moore,

\footnotetext{
- Present address: Research and Development Laboratory, Reckitt and Sons Ltd, Hull.
} 
Sharman \& Ward (1957) was carried out 5,24 and $48 \mathrm{~h}$ after dosing in the 18 th week and 24,48 and $72 \mathrm{~h}$ after dosing in the 39 th week of the experiment.

Expt 2. In a confirmatory experiment, four groups, each consisting of three female and three male rats, were given the diet deficient in vitamin $\mathrm{E}$ and supplements of vitamins $A, D$ and $K$ as described above. The animals were weighed weekly and were given weekly $2.0,2.5,3.0$ or $3.5 \mathrm{mg} \mathrm{DL}$ - $x$-tocopherol $/ \mathrm{kg}$ body-weight in one dose. The haemolysis test was carried out in the Igth and 2oth weeks at 24,72 and $144 \mathrm{~h}$ after dosing.

Table I. Percentage composition of the vitamin E-deficient diet

\begin{tabular}{lc} 
Casein (Vitamin Free, Genatosan Ltd) & 25 \\
Sugar & 50 \\
Lard & 10 \\
Dried yeast powder (Marmite) & 10 \\
Salt mixture (see below) & 5 \\
\multicolumn{1}{c}{$\quad$ Composition of salt mixture (parts) } & \\
Sodium chloride & $5 \circ$ \\
Calcium phosphate $\left(\mathrm{Ca}_{3}\left(\mathrm{PO}_{4}\right)_{2}\right)$ & 400 \\
Ferric citrate $\left(\mathrm{FeC}_{6} \mathrm{H}_{6} \mathrm{O}_{7} \cdot 5 \mathrm{H}_{2} \mathrm{O}\right)$ & 35 \\
Potassium iodide & 1 \\
Magnesium sulphate $\left(\mathrm{MgSO}_{4} \cdot 7 \mathrm{H}_{2} \mathrm{O}\right)$ & 80 \\
Sodium acid phosphate $\left(\mathrm{NaH}_{2} \mathrm{PO}_{4} \cdot 2 \mathrm{H}_{2} \mathrm{O}\right)$ & 150 \\
Potassium chloride & 250 \\
Sodium fluoride & 0.04 \\
Manganese sulphate $\left(\mathrm{MnSO}_{4} \cdot{ }_{4} \mathrm{H}_{2} \mathrm{O}\right)$ & $0 \cdot 2$
\end{tabular}

Table 2. Expt 1. Haemolysis test

\begin{tabular}{|c|c|c|c|c|c|c|c|c|c|c|c|c|c|c|}
\hline \multirow{3}{*}{$\begin{array}{c}\text { Group } \\
\text { no. }\end{array}$} & \multirow{2}{*}{\multicolumn{2}{|c|}{$\begin{array}{l}\text { No. of } \\
\text { animals }\end{array}$}} & \multirow{3}{*}{$\begin{array}{l}\text { Weekly } \\
\alpha \text {-toco- } \\
\text { pherol } \\
\text { intake } \\
(\mathrm{mg} / \mathrm{kg})\end{array}$} & \multirow{3}{*}{$\begin{array}{c}\text { Time of } \\
\text { test } \\
\text { (week) }\end{array}$} & \multirow{2}{*}{\multicolumn{2}{|c|}{$\begin{array}{l}\text { Mean weight } \\
\quad \text { (g) }\end{array}$}} & \multicolumn{8}{|c|}{$\begin{array}{l}\text { Mean percentage haemolysis measured at interval } \\
\text { after dose of: }\end{array}$} \\
\hline & & & & & & & & & & & & & & \\
\hline & $\sigma^{*}$ & $q$ & & & $\sigma$ & $q$ & $\hat{0}$ & q & 0 & $q$ & $\sigma^{*}$ & $q$ & $\sigma^{t}$ & 우 \\
\hline I & 2 & 2 & 2.0 & 18 & 371 & 236 & $2 I$ & 3 & 40 & 5 & 80 & 53 & - & - \\
\hline 2 & 2 & 2 & $2 \cdot 5$ & & 361 & 232 & 9 & I & 8 & 2 & 60 & 4 & - & - \\
\hline 3 & 2 & 2 & 3.0 & & 338 & 250 & 3 & I & 2 & I & 33 & 3 & - & - \\
\hline I & 2 & 2 & 2.0 & 39 & 409 & 204 & - & - & 21 & 2 & 19 & 23 & 87 & 98 \\
\hline 2 & 2 & 2 & 2.5 & & 378 & 192 & - & - & 9 & I & 15 & $I$ & 92 & 2 \\
\hline 3 & 2 & 2 & 30 & & 319 & 255 & - & - & 3 & 0 & 6 & 3 & 39 & 8 \\
\hline
\end{tabular}

\section{RESULTS}

Expt 1. The results of the haemolysis test in the 18 th week are given in Table 2. At this time the mean weekly intakes of $\alpha$-tocopherol by the males were $0.74,0.90$ and $\mathrm{x} \cdot \mathrm{OI} \mathrm{mg}$ and by the females $0.47,0.58$ and $0.75 \mathrm{mg}$ for the three groups. On the lowest level of intake $(2 \cdot 0 \mathrm{mg} / \mathrm{kg})$, slight haemolysis occurred in the males at $5 \mathrm{~h}$ and substantial haemolysis at 24 and $48 \mathrm{~h}$ after dosing, whereas in the females only at $48 \mathrm{~h}$ was there any appreciable haemolysis. On the $2.5 \mathrm{mg} / \mathrm{kg}$ level, less haemolysis occurred in the males than on the lower level, but in the females no appreciable haemolysis was observed at any time. On the highest level of intake haemolysis was only observed in the males $48 \mathrm{~h}$ after dosing. 
In the 39th week, when the mean tocopherol intake of the males was $0.82,0.95$ and $0.95 \mathrm{mg}$ and of the females was $0.4 \mathrm{I}, 0.47$ and $0.76 \mathrm{mg}$ for the three groups, the haemolysis test was carried out at 24,48 and $72 \mathrm{~h}$, because the results at $5 \mathrm{~h}$ in the Igth week showed little haemolysis. The results, also given in Table 2, show that on the lowest level of intake $(2 \mathrm{mg} / \mathrm{kg})$ the only difference between the males and females occurred $24 \mathrm{~h}$ after dosing. On the intermediate level no haemolysis occurred in the females, even after $72 \mathrm{~h}$, whereas in the males haemolysis increased from $9 \%$ at $24 \mathrm{~h}$ to $92 \%$ at $72 \mathrm{~h}$. On the highest level of intake slight haemolysis occurred in the males $72 \mathrm{~h}$ after dosing.

Table 3. Expt 2. Haemolysis test

\begin{tabular}{|c|c|c|c|c|c|c|c|c|c|c|c|c|}
\hline \multirow{3}{*}{$\begin{array}{c}\text { Group } \\
\text { no. }\end{array}$} & \multirow{2}{*}{\multicolumn{2}{|c|}{$\begin{array}{l}\text { No. of } \\
\text { animals }\end{array}$}} & \multirow{3}{*}{$\begin{array}{l}\text { Weekly } \\
\alpha \text {-toco- } \\
\text { pherol } \\
\text { intake } \\
(\mathrm{mg} / \mathrm{kg})^{*}\end{array}$} & \multirow{3}{*}{$\begin{array}{l}\text { Time } \\
\text { of test } \\
\text { (week) }\end{array}$} & \multirow{2}{*}{\multicolumn{2}{|c|}{$\begin{array}{c}\text { Mean weight } \\
\text { (g) }\end{array}$}} & \multicolumn{6}{|c|}{$\begin{array}{c}\text { Mean percentage haemolysis measured at } \\
\text { interval after dose of: }\end{array}$} \\
\hline & & & & & & & & & & & & \\
\hline & $0^{*}$ & \& & & & $\hat{0}$ & 우 & $\sigma^{*}$ & 우 & పే & $\stackrel{0}{T}$ & $\delta$ & ㅇ \\
\hline I & 3 & 3 & $2 \cdot 0$ & $19-20$ & 365 & 220 & 12 & 6 & 82 & 41 & 91 & 83 \\
\hline 2 & 3 & 3 & 2.5 & & 384 & 240 & 8 & 4 & 45 & 9 & 80 & 18 \\
\hline 3 & 3 & 3 & 3.0 & & 370 & 240 & 4 & 3 & 35 & 7 & 87 & 16 \\
\hline 4 & 3 & 3 & 3.5 & & $3^{8} 5$ & 265 & 4 & 3 & 3 & 3 & 23 & 8 \\
\hline
\end{tabular}

Expt 2. The results of the haemolysis tests carried out in the igth and 2oth weeks of the experiment were averaged and are given in Table 3 . During this period the mean weekly tocopherol intake of the males was $0.73,0.96, \mathrm{I} \cdot 10$ and $\mathrm{r} \cdot 35$ and of the females, $0.44,0.60,0.72$ and $0.93 \mathrm{mg}$ for the four groups. Little haemolysis was observed in either the males or females $24 \mathrm{~h}$ after dosing. After $72 \mathrm{~h}$, extensive haemolysis was observed in the males on the lowest level and a moderate degree of haemolysis on the 2.5 and $3.0 \mathrm{mg} / \mathrm{kg}$ levels of intake. In the females only on the lowest level was there any appreciable degree of haemolysis. After $\mathrm{I} 44 \mathrm{~h}$ extensive haemolysis was observed on all but the highest level of intake of the males, when a moderate degree of haemolysis occurred. In the females extensive haemolysis was observed only on the lowest level of intake. It is significant that in all but one instance, which occurred after $72 \mathrm{~h}$ on the highest level, the mean percentage haemolysis for the males was always higher than for the females.

\section{DISCUSSION}

The results of the haemolysis tests in both experiments show clearly that the larger requirement for tocopherol of the male compared with the female rat, as judged by this test, is not due to its larger size. The results suggest that the male rat requires slightly more than a weekly intake of $3.5 \mathrm{mg}$ tocopherol $/ \mathrm{kg}$ body-weight, whereas the female requires about $2.5 \mathrm{mg} / \mathrm{kg}$, corresponding to approximate weekly intakes of $\mathrm{I} .5$ and $0.6 \mathrm{mg}$, respectively, for adult rats.

It is apposite to compare the requirement for tocopherol for prevention of in vitro haemolysis of the erythrocytes with the known requirements for the prevention of other lesions associated with deficiency of vitamin E. The approximate weekly protective doses necessary to prevent some of the lesions are given in Table 4. In male 
rats, with the exception of the defective storage of vitamin $A$, most of the lesions can be prevented by from one-sixth to one-third of the amount required to prevent haemolysis of the erythrocytes. In females about twice as much tocopherol is required to prevent haemolysis as to prevent the other lesions.

\section{Table 4. Minimal requirements of rats for tocopherol}

\begin{tabular}{|c|c|c|}
\hline Criterion & $\begin{array}{l}\text { Approximate weekly } \\
\text { protective dose } \\
(\mathrm{mg})\end{array}$ & Reference \\
\hline Resorption of foetuses & $0.3-0.5$ & Mason (1940-I) \\
\hline $\begin{array}{l}\text { Reduction of hepatic } \\
\text { vitamin A reserves }\end{array}$ & I.0 & Moore (1940) \\
\hline Kidney histolysis & 0.25 & $\begin{array}{l}\text { Moore, Sharman \& } \\
\text { Symonds (1958) }\end{array}$ \\
\hline Uterine pigmentation & 0.25 & Ward $(1958 a)$ \\
\hline Testicular degeneration & $\begin{array}{c}0.35-0.7 \\
0.25\end{array}$ & $\begin{array}{l}\text { Ahmed (1957) } \\
\text { Ward (1958a) }\end{array}$ \\
\hline Haemolysis (male) & $\begin{array}{l}\text { I' } 4 \\
\text { I'5 }\end{array}$ & $\begin{array}{l}\text { Ahmed (1957) } \\
\text { Ward (this paper) }\end{array}$ \\
\hline Haemolysis (female) & 0.6 & Ward (this paper) \\
\hline
\end{tabular}

In view of the fact that the requirements for tocopherol necessary to prevent other lesions typical of the male and female are of the same order, it is difficult to understand why the male requires nearly $2 \frac{1}{2}$ times as much as the female to prevent haemolysis of the erythrocytes. However, it is well known that an important relationship in metabolism exists between vitamin E and highly unsaturated fatty acids. Sinclair (1957, 1958) has even suggested that the main function of tocopherol in the body is to protect the essential unsaturated fatty acids. It is pertinent, therefore, to remember that the optimum requirement for essential fatty acids differs with sex. Already 25 years ago Moore (1937) noticed that the mortality rate in rats given a diet deficient in essential fatty acids was much greater in males than in females. Deuel, Greenberg, Anisfeld \& Melnick (195I) reported that the daily requirement of male rats, based on the maximum gain in weight during the assay period, exceeded $200 \mathrm{mg}$. On the basis of similar experimental results, the daily requirement of the female rat for essential fatty acids did not exceed $100 \mathrm{mg}$ (Anisfeld, Greenberg \& Deuel, 195I). Thus, it is possible that the greater requirement of the male rat for tocopherol could be partly explained by its greater need for essential fatty acids.

\section{SUMMARY}

I. A comparison based on body-weight has been made of the tocopherol requirement of male and female rats as judged by the in vitro haemolysis of erythrocytes.

2. In two experiments, it has been shown that the weekly requirement of the male rat was about $3.5 \mathrm{mg} / \mathrm{kg}$ body-weight, whereas the female required about $2.5 \mathrm{mg} / \mathrm{kg}$ body-weight. These amounts correspond to weekly intakes of about 1.5 and $0.6 \mathrm{mg}$ for adult male and female rats, respectively.

3. These requirements are compared with known requirements for the prevention of other lesions associated with deficiency of vitamin $\mathrm{E}$. 
My thanks are due to Dr T. Moore for valuable criticism, and to Mrs P. J. Richards, Miss M. C. Anable and Mr B. J. Wayman for technical assistance.

\section{REFERENCES}

Ahmed, S. I. (1957). Reproductive organs of the male rat in deficiencies of vitamins E and A. Ph.D. Dissertation, University of Cambridge.

Anisfeld, L., Greenberg, S. M. \& Deuel, H. J. Jr. (1951). F. Nutr. 45, 599.

Deuel, H. J. Jr., Greenberg, S. M., Anisfeld, L. \& Melnick, D. (1951). F. Nutr. 45, 535.

György, P. \& Rose, C. S. (1949). Ann. N.Y. Acad. Sci. 52, 23 I.

Mason, K. E. (1940-1). Amer. F. Physiol. r31, 268.

Moore, T. (1937). Biochem. F. 31, 138.

Moore, T. (1940). Biochem. F. 34, r32 r.

Moore, T., Sharman, I. M. \& Symonds, K. R. (1958). F. Nutr. 65, 183.

Moore, T., Sharman, I. M. \& Ward, R. J. (1957). F. Sci. Fd Agric. 8, 97.

Rose, C. S. \& György, P. (1950). Proc. Soc. exp. Biol., N. Y., 74, 41 I.

Sharman, I. M. \& Richards, P. J. (1960). Brit. F. Nutr. 14, 85.

Sinclair, H. M. (1957). F. roy. Soc. Hlth, 77, 228.

Sinclair, H. M. (1958). Proc. Nutr. Soc. 17, 28.

Taylor, D. W. (1958). F. Physiol. 140, 37.

Ward, R. J. (1958a). Some aspects of the estimation, biological potency and antioxidant activity of the tocopherols. Ph.D. Dissertation, University of Cambridge.

Ward, R. J. (1958b). Biochem. F. 69, 61 P. 